ISSN: 0213-2060

DOI: https://doi.org/10.14201/shhme392153173

\title{
LA ADMINISTRACIÓN DEL ALMIRANTAZGO EN CASTILLA A FINALES DE LA EDAD MEDIA: LOS LUGARTENIENTES DE SEVILLA Y JEREZ DE LA FRONTERA*
}

\author{
The Administration of the Admiralty in Castile in the Late Middle Ages: The Lieutenants \\ of Seville and Jerez de la Frontera
}

Lorenzo LAGE ESTRUGO

Contratado Posdoctoral de la Universidad de Cádiz. Depto. de Historia, Geografia y Filosofía. Área de Historia Medieval. Facultad de Filosofía y Letras. Universidad de Cádiz. Avda. Gómez Ulla, s/n. 11003-Cádiz. C. e.: Lorenzo.lage@uca.es.ORCID: https://orcid.org/0000-0003-1506-3517

Enrique José RUIZ PILARES

Investigador Doctor de la Universidad de Cádiz. Depto. de Historia, Geografía y Filosofía. Área de Historia Medieval. Facultad de Filosofía y Letras. Universidad de Cádiz. Avda. Gómez Ulla, s/n. 11003-Cádiz. C. e.: enrique.pilares@uca.es. ORCID: https://orcid.org/0000-0002-8624-0667

RESUMEN: El almirantazgo de Castilla desde su creación por Alfonso X vivió una profunda transformación desde un oficio de carácter militar a un cargo cortesano. En el siglo $\mathrm{Xv}$, cuando fue patrimonializado por el linaje noble de los Enríquez, sus atribuciones se circunscribían a la justicia y a la percepción de una serie de rentas en el ámbito marítimo, cuya jurisdicción «real» — y no exenta de problemas - era ejercida sobre el reino de Sevilla. Asentados en Medina del Rioseco, los Enríquez delegaron el ejercicio de su oficio en una serie de lugartenientes, en ocasiones criados, en otros casos hombres de negocios dedicados al arrendamiento de impuestos. A mediados del siglo xv, uno controló Sevilla y el territorio al norte del Guadalquivir, otro, por su parte, tenía jurisdicción al sur de este río, con sede

* Este trabajo forma parte de las actuaciones de dos proyectos de investigación interconectados: «La integración sociedad-medio ambiente en la cuenca del Guadalete en la Edad Media (GUADAMED), cofinanciado por la Unión Europea en el marco del Programa Operativo FEDER 2014-2020 y por la Consejería de Economía, Conocimiento, Empresas y Universidad de la Junta de Andalucía (Referencia del proyecto: 108201) y «El mar como frontera. Transgresiones legales en el Atlántico bajomedieval» (referencia PGC2018095719-B-I00), financiado por el Ministerio de Educación de España.

Siglas: $\mathrm{ADA}=$ Archivo Ducal de la Casa de Alba; AGA = Archivo General de Andalucía; AGS = Archivo General de Simancas; AGI = Archivo General de Indias; AHN = Archivo Histórico Nacional; AMJF = Archivo Municipal de Jerez de la Frontera; AC = Actas Capitulares; CRC = Consejo Real de Castilla. 
en Jerez de la Frontera. Este trabajo profundizará en el perfil y procedencia social de estos personajes, especialmente en este último espacio.

Palabras clave: almirantazgo; lugarteniente; arrendamiento; reino de Sevilla; Jerez de la Frontera; siglo Xv.

ABSTRACT: The admiralship of Castile since its creation by Alfonso X went through a deep, profound transformation from its roots as a mostly military office to a courtly one. In the 15th century, when it was capitalized by the aristocratic lineage of the Enríquez, their fundamental traits were circumscribed around the exercise of Justice and the perception of a variety of rents in the maritime field, whose actual jurisdiction was exerted on the kingdom of Seville. Settled in Medina del Rioseco, the Enriquez delegated the exercise of its office in a series of lieutenants, sometimes servants and often businessmen focused on the leasing of taxes, customs and rents. By the mid- $15^{\text {th }}$ century, one controlled Seville and the territory North of the Guadalquivir, while a second controlled the land South the said river with seat in Jerez de la Frontera. This work will try to ascertain the role, profile and provenance of these characters, particularly in the aforementioned territory.

Keywords: admiralship; lieutenants; lease; kingdom of Seville; Jerez de la Frontera; $15^{\text {th }}$. century.

SUMARIO: 0 Introducción. 1 El almirantazgo a finales de la Edad Media: Fadrique Enríquez de Cabrera. 2 Los hombres del almirante: la figura del lugarteniente. 3 Un caso de estudio. la lugartenencia de Jerez y sus «puertos comarcanos». 4 Conclusiones. 5 Referencias bibliográficas.

\section{INTRODUCCIÓN}

En el siglo XIII se definen dos ámbitos diferenciados dentro de los grandes oficios del reino: las dignidades de carácter doméstico y las de una tipología jurisdiccional, con una vertiente territorial. Alfonso X, rey de Castilla y León, recoge las tradiciones legales e institucionales imperantes en la Europa del momento y configura toda una serie de nuevos oficios para el gobierno de los cada vez más complejos y diversificados asuntos dependientes de la corona. Entre ellos, el almirantazgo, heredero de una antigua y compleja trayectoria italiana, tanto genovesa como siciliana ${ }^{2}$. En un inicio, el almirante se concibió como un gestor de la importante y compleja logística involucrada en el mantenimiento de una flota castellano-leonesa permanente ${ }^{3}$. A lo largo del siglo xIv la institución se dota

2 Houben, Hubert. Roger II of Siciliy: a ruler between East and West. Cambridge: Cambridge University Press, 2002, p. 150; Calderón Ortega, José Manuel. El almirantazgo de Castilla: historia de una institución conflictiva. Alcalá de Henares: Universidad de Alcalá de Henares, Fundación duque de Alba, 2003, pp. 154155; Unger, Richard W. «Admiralties and Warships of Europe and the Mediterranean». En Unger, Richard W. Ships and Shipping in the North Sea and Atlantic, 1400-1800. Oxford: Routledge, 2018, pp. 34-42.

3 Calderón Ortega, José Manuel y Díaz González, Francisco Javier. «Los almirantes y la política naval de los reyes de Castilla en el siglo xiII". Anuario de la Facultad de Derecho, 1988-1989, vol. 8, pp. 108-113. 
LA ADMINISTRACIÓN DEL ALMIRANTAZGO EN CASTILLA A FINALES DE LA EDAD MEDIA: LOS LUGARTENIENTES DE SEVILLA Y JEREZ DE LA FRONTERA

de un importante lustre marcial, derivado del ejercicio de competentes almirantes, como Alonso Jofré Tenorio, Egidio Bocanegra o Fernán Sánchez de Tovar. Sin embargo, a partir de inicios del siglo xv el oficio se patrimonializa dentro del linaje de los Enríquez, una rama secundaria y bastarda de la casa real castellano-leonesa, descendiente de Alfonso XI y Leonor de Guzmán ${ }^{4}$.

Los primeros Trastámara favorecieron a sus parientes ilegítimos con diversas posesiones y prebendas, así como con el propio almirantazgo. En dicho siglo se ve una nueva transformación del oficio. Tras el fin de las campańas de Fernando de Antequera, futuro Fernando I de Aragón, y la conclusión del escenario marítimo de dicha guerra, prácticamente el almirantazgo permanece inactivo en su rol logístico y militar ${ }^{5}$. El titular del oficio, fuera cual fuese, se consagró a partir de ese momento a intrigas cortesanas y la alta política, a la que tenía acceso como gran ricohombre del reino, miembro del consejo del rey y de su casa. El oficio perdió su relevancia real. El foco de la institución derivó entonces a la percepción de rentas y la gestión de elementos hacendísticos relacionados con el control teórico del almirante sobre el tráfico marítimo y el comercio ${ }^{6}$.

La jurisdicción del almirantazgo tenía una vertiente territorial clara, el litoral atlántico del reino de Sevilla (Mapa 1). Inicialmente, la institución estaba centrada en la gestión de la flota real fletada para combatir en el Estrecho de Gibraltar; incluso originalmente se encuentran menciones al almirante "de la costa de Andalucía» o "de Sevilla». Fuera de dicho territorio la incidencia de su jurisdicción y sus agentes fue bastante limitada, por no decir escasa. Allí se harán efectivas la percepción de las rentas asociadas a la institución del almirantazgo, incluyendo el cobro de los derechos sobre las cosas vedadas o la saca del pan, ambas adscritas al oficio por ser comercios eminentemente marítimos ${ }^{7}$. Sin embargo, era una zona compleja, un mosaico jurisdiccional en el cual se encontraban tanto pujantes señores regionales, ejemplo de lo cual eran los Guzmanes y los Ponce de León, como poderosos gobiernos concejiles — Jerez de la Frontera y Sevilla ${ }^{8}$. Será en este espacio donde tendrán que actuar los oficiales que será objeto de estudio en este trabajo: los lugartenientes. Para comprender la naturaleza de este oficio en el tránsito de la Edad Media a la Modernidad, es fundamental conocer el contexto de la institución del almirantazgo en esas décadas, durante las cuales estuvo al frente un longevo e influyente almirante.

4 Mitre Fernández, Emilio y González Crespo, Esther. «El Maestre don Fadrique y su descendencia en la formación de la nobleza trastamarista». Hidalguia: la revista de genealogía, nobleza y armas, 2016, vol. 373, pp. 798-808.

Muñoz Gómez, Victor. «Compañeros de armas: ejemplos de sociabilidad en las fronteras marítimas ibéricas durante el reinado de Fernando I de Aragón». Vegueta, 2018, vol. 18, pp. 133-166.

6 Sobre el particular véase un estudio de caso en Lage Estrugo, Lorenzo. «El Almirantazgo y la Bahía de Cádiz en la Baja Edad Media: Competitividad señorial, rentas alienadas y proyectos frustrados». Riparia, 2019, Suplemento 2, pp. 143-172.

7 Aznar Vallejo, Eduardo. «Las rentas del Almirantazgo castellano. Entre la ley y la costumbre». En la España Medieval, 2014-2015, vol. 37, pp. 146-155.

8 Ladero Quesada, Miguel Ángel. «Los señoríos medievales en el ámbito de Cádiz y Jerez de la Frontera». En la España Medieval, 1982, vol. 2, pp. 543-572; Collantes de Terán Sánchez, Antonio. «Los señoríos andaluces. Análisis de su evolución territorial en la Edad Media». Historia. Instituciones. Documentos, 1979, vol. 6, pp. 89-112; Ruiz Pilares, Enrique José. La sociedad politica de Jerez de la Frontera a finales de la Edad Media, Cádiz: Universidad de Cádiz, 2020, pp. 181-196. 
MAPA 1. El ámbito jurisdiccional marítimo del almirante de Castilla (finales siglo xv) ${ }^{9}$

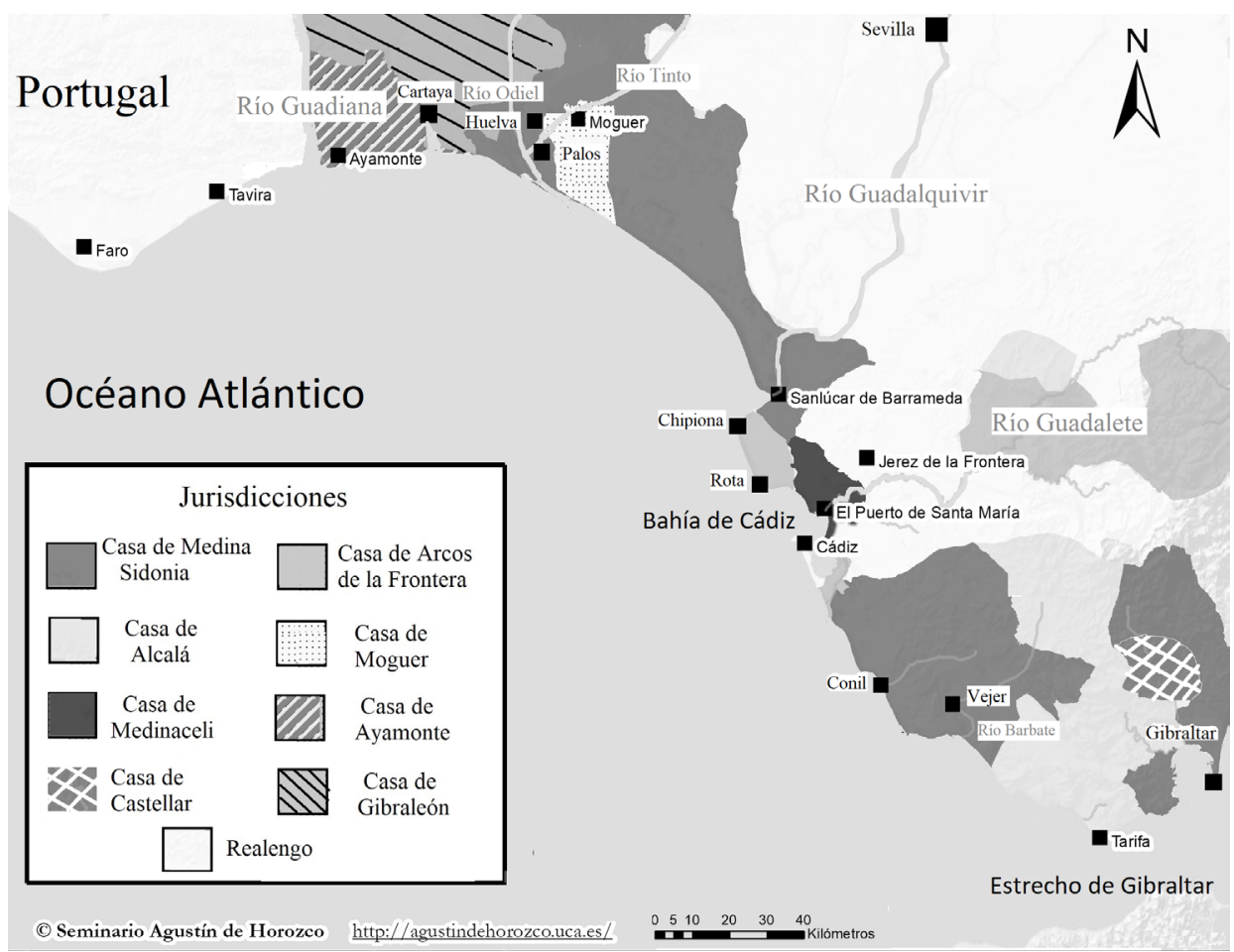

1 El almirantazgo a finales de la Edad Media: Fadrique Enríquez de Cabrera

Entre finales del xv e inicios del siglo xvi, concretamente entre 1485 y 1538 , el almirantazgo fue ejercido por un único titular, bastante complejo y polifacético, Fadrique Enríquez de Cabrera, conde de Módica. A la muerte de su padre y antecesor en el oficio, Alonso Enríquez, se encuentra con una institución endeudada por las rentas perdidas, durante la vida de su abuelo Fadrique Enríquez — que había apoyado a los infantes de Aragón frente a Álvaro de Luna y el rey Juan II de Castilla-, y muy disminuida en su alcance y poder efectivos. El largo ejercicio del oficio por parte del almirante y su cercanía a los Reyes Católicos — la madre del monarca era dońa Juana Enríquez, tía de don Fadrique - permitirán una recuperación constante de privilegios hacendísticos y rentistas

9 Esta cartografía ha sido elaborado con los recursos SIGs del Seminario Agustín de Horozco de Historia Antigua y Medieval de la Universidad de Cádiz (https://agustindehorozco.uca.es/) a partir de los datos proporcionados por parte de la bibliografía de este trabajo, especialmente los mencionados en la nota 8 . 
de manos de aquellos que los habían usurpado a lo largo de las décadas anteriores. El almirante castellano fue un importante miembro de la casa real, siendo mayordomo de los monarcas, y en bastantes ocasiones éstos recompensaron su lealtad fallando a su favor en los numerosos pleitos que provocaban los intentos de Fadrique Enríquez por recobrar su jurisdicción ${ }^{10}$.

La muerte de Isabel la Católica en 1504 inauguró un nuevo período en la corona de Castilla. El almirante abandonó el bando de su primo, el rey don Fernando, pasando a apoyar al archiduque Felipe y a la reina Juana, efímeramente, lo cual le valió la creación del almirantazgo de Granada en 1505 por orden real enviada desde Bruselas. Posteriormente, una nueva aproximación a Fernando el Católico le valdría la confirmación del título en 1510, junto con toda una serie de extensos privilegios arancelarios. Desafortunadamente para el almirante, en los puertos andaluces, sobre todo de aquellos en territorio granadino — especialmente Málaga — tuvo lugar una revuelta abierta contra la institución, sus agentes y sus privilegios ${ }^{11}$. Dicha resistencia llevaría al fracaso al proyecto de Fadrique Enríquez de extender su jurisdicción por Andalucía Oriental. El descubrimiento y conquista de los territorios americanos fue un nuevo síntoma de la obsolescencia del almirantazgo en Castilla. Cristóbal Colón fue nombrado almirante de la Mar Océana, sustrayendo todas las tierras descubiertas - y la mayor parte de las potenciales rentas y jurisdicciones asociadas - a Fadrique Enríquez ${ }^{12}$.

El reinado de Carlos I devengaría en nuevos beneficios para el almirante: el veterano don Fadrique fue nombrado gobernador del reino y principal representante de los magnates castellano-leoneses y sus intereses. En dicha responsabilidad permaneció durante la Guerra de las Comunidades (1520-1522), durante la cual se ocupó de liderar tropas realistas ${ }^{13}$. Fadrique conservaría su ascendente en la corte, siendo una presencia constante en Castilla e incluso en Aragón, a donde acompañaría a su soberano ${ }^{14}$. Sin embargo, a su muerte en 1538 el almirantazgo perdería toda relevancia e incluso casi todas sus rentas — incluida su jurisdicción sobre el reino de Granada-. Carlos I no renovó todos los privilegios con los que contó en vida en la persona de su hermano menor y sucesor, Hernando Enríquez. Aunque, en contrapartida, el emperador le concedió un ducado

10 Ortega Gato, Esteban. «Los Enríquez, almirantes de Castilla». En Publicaciones de la Institución Tello Téllez de Meneses, 1999, vol. 70, pp. 37-39.

11 Véase sobre el particular Calderón Ortega, El almirantazgo de Castilla, pp. 7-50; Cruces Blanco, Esther, López de Coca Castañer, José Enrique y Ruiz Povedano, José María (coords.). Málaga y el almirantazgo mayor del reino de Granada (1510-1538). Revolución y poder. Málaga: Fundación Unicaja, 2017.

12 Lage Estrugo, Lorenzo. «El almirantazgo de la mar océana de Cristóbal Colón y el almirantazgo castellano medieval». En Barrientos Márquez, María del Mar y Gullón Abao, Alberto (coords.). América y el Mar. Cádiz: Universidad de Cádiz, 2019, pp. 25-30; AGI, PATRONATO, 295, n. ${ }^{\circ} 124$.

13 Fernández Conti, Santiago. "Carlos V y la alta nobleza castellana: el almirante don Fadrique Enríquez». En Martínez Millán, José, Rivero Rodríguez, Manuel y Álvarez-Ossorio Alvariño, Antonio (coords.). Carlos Vy la quiebra del humanismo politico en Europa (1530-1558), Madrid: Sociedad Estatal para la Conmemoración de los centenarios de Carlos V y Felipe II, 2001, p. 31; Soria Mesa, Enrique. La nobleza en la España moderna: cambio y continuidad. Madrid: Marcial Pons, 2007, p. 83.

14 Fernández Conti, «Carlos V y la alta nobleza castellana», p. 35. 
con grandeza de Espańa sobre su villa de Medina del Rioseco a la muerte de Fadrique ese mismo año de $1538^{15}$.

\section{LOS HOMBRES DEL ALMIRANTE: LA FIGURA DEL LUGARTENIENTE}

Los múltiples derechos del almirantazgo eran raramente percibidos directamente por el almirante en sí mismo. Los titulares de la institución estaban frecuentemente centrados en ejercer su rol dentro de la casa del rey y en la corte castellano-leonesa ${ }^{16}$. Sin embargo, ni podían ni querían descuidar toda una serie de ingresos patrimoniales asociados a su jurisdicción, entre ellos derechos sobre el flete de navíos, el grindaje y el ramaje, un porcentaje del quinto real, la saca del pan o la disputada saca de las cosas vedadas ${ }^{17}$. Eran derechos muy variados en su naturaleza y particularmente flotantes en su monto total, ya que dependían de numerosos factores. Primero, la capacidad de imposición de la jurisdicción del almirantazgo por sus agentes. Segundo, el volumen comercial y sus inherentes fluctuaciones. Tercero, la entidad de las capturas y botines de los cuales el almirante recibía un porcentaje. Cuarto, el impago y el fraude fiscal, difíciles de trazar. En quinto y último lugar, la posible existencia de abusos y mala gestión por parte de los arrendatarios. Además, necesitaban de una atención constante, ya que muchos de ellos eran particularmente complejos de administrar correctamente o relativamente sencillos de esquivar por parte de numerosos agentes que buscaban cometer dicho fraude o incluso subvertir la jurisdicción del almirante. Teniendo en cuenta, por otro lado, que los derechos estaban centrados en la costa andaluza occidental y que el almirante raramente pisaba las tierras del reino de Sevilla, había desde un inicio una necesidad intrínseca de mantener un agente especializado que gestionara los derechos arancelarios del almirantazgo sobre el terreno. A todo ello deben ańadirse la pléyade de elementos jurisdiccionales derivados del ejercicio de la justicia por parte del almirante, que tenía potestad sobre todos los asuntos y hombres de la mar, para lo cual tenía su propio tribunal y patíbulo en la capital hispalense ${ }^{18}$.

15 AGS, CCA, DIV,6,34.

16 A modo de ejemplo, el almirante Fadrique estaba presente durante el aseo del hijo de los monarcas; Fernández de Oviedo, Gonzalo [1548], edición de Fabregat Barrios, Santiago. Libro de la Cámara Real del Principe Don Juan, oficios de su casa y servicio ordinario. Valencia: Universidad de Valencia, 2006, p. 95; González Arce, José Damián. «Trabajar para el príncipe. Los salarios de los servidores en la casa del príncipe de Asturias y Gerona (Juan de Aragón y Castilla, 1478-1497)». Anuario de Estudios Medievales, 2009, vol. 39, n. ${ }^{\circ} 2$, p. 823; Fernández Conti, «Carlos V y la alta nobleza castellana», pp. 29-32.

17 Calderón Ortega, El almirantazgo de Castilla, pp. 377-383.

18 No había mayor y mejor expresión de la jurisdicción del almirante que la existencia de un patíbulo público de la institución. En Málaga, sede del almirantazgo de Granada, se levantó también una horca, que fue luego derribada durante una revuelta de 1516. En Sevilla, el patíbulo del Almirante se encontraba en el Arenal, y fue derribado en 1545, año en el que también desapareció la cárcel que hasta entonces había poseído, Calderón Ortega, El almirantazgo de Castilla, p. 29. En Jerez se levantaba una horca cuando era necesario junto al embarcadero existente junto al río Guadalete, artería que conectaba la ciudad con la Bahía de Cádiz, AMJF, AC, 1484, fol. 112v. 
La ausencia física y la distancia emocional del almirante, así como su deseo de obtener un beneficio directo y sin mayores complicaciones, probablemente fueron los desencadenantes de la cesión de los derechos de la institución en el reino de Sevilla a unos terceros, agentes privados, que fueron denominados lugartenientes. Desde un inicio este oficio se asocia a una serie de personajes sevillanos, pertenecientes a linajes señalados dentro de la ciudad, con suficiente poder adquisitivo e intereses económicos diversificados como para ser parte importante de la vida económica y política de la urbe ${ }^{19}$. Estos accedieron a esta responsabilidad mediante la cesión por arrendamiento. El almirante ganaba una seguridad económica que la percepción directa de las rentas, siempre flotantes ya que dependía de factores externos, quizás no hubiera permitido. Por ello, se puede considerar al almirantazgo en sí mismo como una complejísima y polifacética renta que, asociada a un título de carácter oficioso y honorífico sin prácticamente ninguna responsabilidad asociada más allá de una participación testimonial en cuestiones marítimas.

Los arrendadores ganaban un lucrativo negocio, con el cual. podían incidir en la vida económica sevillana explotando una serie de derechos que incidían en el comercio fluvial y marítimo, así como percibiendo ingresos derivados del ejercicio de justicia. Asimismo, la lugartenencia en sí otorgaba cierta relevancia social y política en un escenario, el sevillano, bastante complejo con multitud de grandes actores y una rivalidad intensa por el control de ciertas parcelas de $\operatorname{poder}^{20}$. El arrendador pasaba a ser el delegado y representante del Almirante Mayor de Castilla, una de las grandes dignidades seculares del reino, ostentado por un miembro de un poderoso linaje con sangre real y emparentado directamente con los monarcas. Sin duda los arrendadores intentarían sacar un beneficio elevado de la que era una igualmente alta inversión económica, ya que según se trasluce de los contratos de arrendamiento conservados, el coste no era para nada desdeńable ${ }^{21}$.

La caracterización social de los lugartenientes en los dos primeros tercios del siglo $\mathrm{XV}$ es similar. Pertenecen a linajes de extracción media, que, aunque en ocasiones incluso poseen señoríos y tierras no pueden compararse con las grandes familias de extracción sevillana, como los Ribera, los Ponce de León o los Guzmán. Ejemplo de ello son los Marmolejo $^{22}$, padre e hijo, que ocuparon la lugartenencia y tenían participación en el concejo hispalense, o los Álvarez de la Becerra, también con idéntica relación familiar, y similares características económicas y contexto social (Tabla 1). Pertenecían a un círculo social que pese a su supuesta extracción caballeresca eran partícipes de la vida comercial de la ciudad y tenían pericia económica suficiente como para gestionar los dispersos derechos del almirantazgo y obtener beneficios ${ }^{23}$.

19 Calderón Ortega, El almirantazgo de Castilla, pp. 203-212; Ladero Quesada, Miguel Ángel. Andalucía a fines de la Edad Media: estructuras, valores, sucesos. Cádiz: Universidad de Cádiz, 1999, pp. 140-145.

20 Para conocer la compleja realidad política hispalense véase el trabajo de Sánchez Saus, Rafael, Linajes sevillanos medievales. Sevilla: Ediciones Guadalquivir, 1991.

21 Aznar Vallejo, "Las rentas del Almirantazgo", pp. 132-135.

22 Sánchez Saus, Rafael, Linajes sevillanos medievales. Sevilla: Editorial Guadalquivir, 1991, pp. 118120.

23 Que un linaje sevillano arrendara un oficio con rentas devengadas de la actividad económica mercantil y marítima no es incongruente. Idénticas motivaciones se encuentran en aquellos que arrendaban almojarifazgos, la percepción de alcabalas, el diezmo del aceite y otras imposiciones arancelarias similares. Cargos como la guarda mayor de la saca del pan, el almojarifazgo mayor, el alcalde de las sacas y cosas vedadas, 
LORENZO LAGE ESTRUGO Y ENRIQUE JOSÉ RUIZ PILARES

LA ADMINISTRACIÓN DEL ALMIRANTAZGO EN CASTILLA A FINALES DE LA EDAD MEDIA: LOS LUGARTENIENTES DE SEVILLA Y JEREZ DE LA FRONTERA

Tabla 1. Lugartenientes del reino de Sevilla (c. 1397-1480)24.

\begin{tabular}{|l|l|l|}
\hline \multicolumn{1}{|c|}{ Nombre } & \multicolumn{1}{c|}{ Ańos } & \multicolumn{1}{c|}{ Otros datos } \\
\hline Francisco Imperial & c. $1397-1403$ & genovés \\
\hline Fernán Yánez de Mendoza & c. 1400 & vecino de Sevilla \\
\hline Pedro de Pineda & $1416-1419$ & vecino de Sevilla \\
\hline Pedro Barba íde Campos? & $1425-1427$ & ¿̨marino?; vecino de Sevilla \\
\hline Luis Fernández de Marmolejo & $1427-36$ & arrendador \\
\hline Diego Álvarez de Becerra & $1437-1445$ & arrendador \\
\hline Ruy Sánchez de Huete & $1445-1454$ & recaudador real \\
\hline Gonzalo López de Sevilla & 1453 & recaudador real \\
\hline Diego López de Sevilla & 1454 & arrendador; vecino de Sevilla \\
\hline Diego Álvarez de la Becerra & $1454-1455$ & arrendador; vecino de Sevilla \\
\hline $\begin{array}{l}\text { Rodrigo Álvarez de la Becerra } \\
\text { (hijo del anterior) }\end{array}$ & $1455-1456$ & arrendador; vecino de Sevilla \\
\hline Alfonso de Valladolid & $1457-1460$ & criado del almirante \\
\hline Juan Barba & $1463-1464$ & arrendador; vecino Sevilla \\
\hline Pedro Barba & 1464 & arrendador, vecino Sevilla \\
\hline Juan Sánchez de Bilbao & $1464-1465$ & criado y secretario del almirante \\
\hline Juan Fernández de Marmolejo & $1466-1468$ & arrendador; vecino de Sevilla \\
\hline Juan Sánchez de Bilbao & 1468 & criado del almirante \\
\hline Arias de Cifuentes & $1469-1470$ & ¿criado del almirante? \\
\hline Juan Sánchez de Bilbao & $1469-1470$ & criado y secretario del almirante \\
\hline Pedro Fernández de Marmolejo & 1471 & arrendador; vecino de Sevilla \\
\hline Fernando de Ribadeneira & $1470-1478$ & criado del almirante \\
\hline Tristán de Villaroel & 1473 & criado del almirante \\
\hline Diego de Mesa & 1477 & criado de almirante \\
\hline Ruy González del Portillo & $1478-1480$ & vecino de Valladolid \\
\hline
\end{tabular}

estaban en manos de individuos de similares intereses y trasfondo social. Todos ellos esperaban un fuerte rembolso, ya que el arrendamiento de la lugartenencia estaba cifrado en unos 900.000-910.000 maravedíes anuales en tiempos de don Fadrique Enríquez de Cabrera. Monte significativo teniendo en cuenta estos señalados linajes urbanos —ni alta ni baja nobleza — solían tener unas fortunas personales valoradas en torno 2.000.000 a 6.000.000 de maravedíes, con lo cual entregaban en forma de arrendamiento lo que probablemente fuera una porción considerable de sus rentas anuales, Montes Romero-Camacho, Isabel. «Las instituciones de la saca en la Sevilla del siglo xv: aproximación al estudio de la organización del comercio exterior de la corona de Castilla al final de la Edad Media». Historia. Instituciones. Documentos, 2004, vol. 31, pp. 417-436, pp. 426-436; Aznar Vallejo, «Las rentas del Almirantazgo», pp. 132-135; Ladero Quesada, Andalucía a fines de la Edad Media, pp. 140-145.

24 Calderón Ortega, El Almirantazgo, p. 213; Navarro Sainz, José María. El concejo de Sevilla en el reinado de Isabel I. Sevilla: Universidad de Sevilla, tesis doctoral inédita (https://idus.us.es/handle/11441/15219), p. 43 y 265; AMJF, AC, 1454, fol. 19v; 1456, fol. 28v; 1464, fol. 80r; 1466, fol. 11r; 1468, fol. 141r; 1471 fol. 26r; 1480; fol. 4r. 
El arrendamiento provocaba una búsqueda constante de beneficio, lo que probablemente condujera a un excesivo celo en la percepción de los derechos en usufructo por parte del lugarteniente. Ello, a su vez, podría ser la causa de las numerosas quejas elevadas por organismos como el concejo hispalense frente al almirantazgo y del constante deseo de grandes señores por evitar el pago rutinario de estos derechos rentísticos ${ }^{25}$. Hay constancia de abuso por parte de los lugartenientes del almirantazgo, incluyendo su demanda de pago de derechos por parte de las naves que circularan por el río tras examinar su mercancía, pese a que algunos de dichos derechos no les correspondían. Claramente ello derivaba de una avaricia excesiva de los arrendatarios, buscando aumentar su margen de beneficios. Teniendo en cuenta la importancia del comercio en Sevilla y su reino, abusos de este tipo eran extrańamente tolerados por el concejo. Entonces, era el almirantazgo en sí el que debía resolver dichos conflictos mediante eternos pleitos que en ocasiones requerían el fallo de la corona ${ }^{26}$.

Cuando el desgobierno de los asuntos y derechos del almirantazgo llegaba a límites insospechados era necesaria la suspensión de los arrendamientos y el envío de alguien de total confianza para el propio almirante. Ahí entra la segunda tipología de lugartenientes, los criados de su casa. Esta serie de personajes, inferiores en número a los arrendatarios, asumían las funciones del almirantazgo en momentos concretos de crisis. Miembros de la casa del almirante o de su círculo de colaboradores cercanos, un número de ellos provenían del entorno de los propios estados patrimoniales de los Enríquez, en Tierra de Campos, Valladolid. Sus patronímicos incluso harían pensar en conversos, como, por ejemplo, Alonso de Valladolid (Tabla 1). Debe tenerse en cuenta que el almirante celebraba en su asiento de Medina de Rioseco una próspera serie de ferias, parte del círculo ferial castellano, que incluía villas como Medina del Campo o Villalón ${ }^{27}$. La celebrada en territorios de los Enríquez no llegó nunca a eclipsar la gran feria de Medina del Campo, que fue uno de los grandes centros financieros de la Europa del momento, pero sí fue lo suficientemente pujante como para ser una competidora directa. El patrocinio del almirante de una feria en el corazón de sus estados señoriales debía, forzosamente, vincularlo con los círculos financieros y comerciales de la región, dándole acceso a personajes versados en la gestión de cuestiones de dicha índole.

Sin embargo, reducir la lugartenencia a Sevilla y su entorno inmediato es un error de cálculo. Los derechos del almirantazgo abarcaban el arzobispado hispalense y el obispado

25 Los grandes señores andaluces tenían en posesión varias importantes plazas portuarias, como Rota, Sanlúcar, Cádiz, el Puerto de Santa María o Chipiona, González Arce, José Damián. «Pugnas entre monarquía y aristocracia por el control de los almojarifazgos costeros y otros derechos aduaneros de la Andalucía atlántica en el reinado de los Reyes Católicos». Anuario de Estudios Medievales, 2017, vol. 47, n. ${ }^{\circ}$ 1, pp. $77-$ 81; Franco Silva, Alfonso. Estudios sobre la nobleza y el régimen señorial en Andalucía, siglos XIV-mediados del XVI. Granada: Editorial Universidad de Granada, 2006, pp. 226-238; Ladero Quesada, Andalucía a fines de la Edad Media, pp. 106-116.

26 Aznar Vallejo, «Las rentas del Almirantazgo», p. 141.

27 Martínez Sopena, Pascual. El estado señorial de Medina de Rioseco bajo el almirante Alfonso Enríquez (1389-1430). Valladolid: Universidad de Valladolid, 1977, pp. 153-157; Casado Alonso, Hilario. "Comprar y vender en las ferias de Castilla durante los siglos Xv y XVI». En Faire son marché au Moyen Âge: Mediterranée occidentale, XIIT-XVT siècle. Madrid: Casa de Velázquez, 2018, pp. 111-131. 
gaditano, incluyendo una zona de enorme relevancia económica y marítima, la Bahía de Cádiz. Ha de tenerse en cuenta la profunda interrelación entre el centro financiero y económico de Sevilla con el pulmón comercial de la Bahía de Cádiz. Aparte, dicho territorio abarca la mayor parte de los puertos y plazas costeras andaluzas - Cádiz, Sanlúcar, el Puerto de Santa María, Rota, posteriormente Puerto Real—, donde realmente se percibían casi todos los derechos del almirantazgo. La región era un poliédrico ecosistema humano, donde se encontraban interconectadas una serie de ciudades y sus espacios dependientes, creando un complejo portuario y económico de primer nivel dentro de la corona castellano-leonesa, funcionando como una unidad territorial con un gran peso comercial y coherencia interna ${ }^{28}$. Jerez y su campiña actuaban como espacio agrícola y productivo; Cádiz era la residencia de comerciantes extranjeros y un puerto adecuado; Sanlúcar se estableció como la gran entrada al espacio sevillano a través del Guadalquivir; el Puerto de Santa María se constituyó en un gran centro pesquero y naval; Puerto Real era el único lugar de realengo en la propia Bahía. Todas las villas estaban económicamente interconectadas: los productos cultivados y procesados en Jerez y su entorno eran enviados a localidades portuarias de la región para su venta y embarque, mientras que desde Cádiz se gestionaban toda clase de negocios y se recibían barcos y productos del Mediterráneo $^{29}$. Con ello, el ámbito de actuación del lugarteniente del almirante no se ceñía al espacio meramente sevillano, sino también a la muy compleja Bahía de Cádiz. Esta doble faceta territorial de la lugartenencia se irá sobredimensionando, conduciendo a un desdoblamiento progresivo de dicha delegación de derechos y responsabilidades, provocando la aparición de un nuevo lugarteniente en la década de 1480 - con antecedentes y probaturas anteriores - en el litoral gaditano. Este oficial, radicado en Jerez de la Frontera, aunque dependiente del de Sevilla en su nombramiento, tenía un gran margen de actuación; como ejemplificó el jerezano Luis Ortiz de Gatica a comienzos del siglo XVI.

\section{Un CASO DE ESTUdio. LA LUGARTENENCIA DE JEREZ «Y SUS PUERTOS COMARCANOS»}

Desde el primer lugarteniente conocido -1397- el oficio abarcaba la jurisdicción de todo el reino hispalense. Ésta fue ejercida en Jerez y su comarca a través de personas

28 Varios autores han profundizado en la naturaleza territorial y económica de la Bahía de Cádiz, desde su participación en el comercio europeo hasta las conexiones entre éste y el espacio agrícola, pasando por la próspera industria vitivinícola local, el rol de las élites sociales en estas actividades económicas y la presencia de extranjeros en la zona. Véanse, especialmente, Martín Gutiérrez, Emilio y Ruiz Pilares, Enrique José. El vinedo en Jerez de la Frontera durante el siglo XV. Un mercado de trabajo en torno al vino. Jerez de la Frontera: Peripecias Libros, 2019; González Zalacaín, Roberto. «De puerto a puerto: las relaciones entre los puertos de la Bahía de Cádiz (siglos Xv-Xvi)». En Aznar Vallejo, Eduardo y González Zalacaín (coords.). De mar a mar: los puertos castellanos en la Baja Edad Media. La Laguna: Universidad de la Laguna, 2015, pp. 147-178; Bello León, Juan Manuel. «Mercaderes del siglo xv en Jerez de la Frontera». Historia. Instituciones. Documentos, 2014, vol. 41, pp. 11-44.

29 Ruiz Pilares, Enrique José. «Jerez de la Frontera: el gran centro productor del complejo portuario de la Bahía de Cádiz a finales de la Edad Media». Estudios sobre Patrimonio, Cultura y Ciencias Medievales, 2018, vol. 20, pp. 355-386. 
delegadas que se encargaban de gestionar los derechos del almirante en la zona. Así lo confirman las actas capitulares jerezanas. En 1454 la persona que se encontraba en Jerez en nombre del lugarteniente era Bartolomé de Écija, alguasil del almirante, quien anunció el 27 de junio ante el concejo la visita de su superior, el lugarteniente Pedro Barba ${ }^{30}$.

En 1455 tuvo lugar un episodio bastante controvertido que indica la tendencia por parte de los almirantes de separar la jurisdicción entre los territorios al norte y al sur del río Guadalquivir. El 1 de septiembre se presentó ante el concejo de Jerez Rodrigo Álvarez de la Becerra, lugarteniente del almirante en Sevilla, reclamando que se le reconociese también como máxima autoridad del almirantazgo en la ciudad y su comarca. Para ello presentó una carta de nombramiento firmada por el almirante fechada a 18 de abril ${ }^{31}$. Sin embargo, la ciudad había reconocido como lugarteniente al regidor jerezano Alvar Núñez Cabeza de Vaca, que había presentado un nombramiento del almirante fechado a 8 de agosto. Este personaje, descendiente de una familia de reconocidos marinos, era pariente del almirante Fadrique Enríquez ${ }^{32}$. Según Álvarez de la Becerra, el oficial jerezano ejercía su oficio:

en Jeres e en sus términos dando liçençias e albalaes para sacar pan por la mar e llevando derechos de las tales liçençias e albalaes e poniendo guardas en El Puerto de Santa María [...] e por virtud del dicho poder vsando del como su lugarteniente ha puesto las dichas rentas e ofiçios e derechos del dicho almirantadgo desta dicha çibdad e sus términos que, al dicho almirante, mi señor, pertenesçe con las guardas e saca en almoneda ${ }^{33}$.

Álvarez de la Becerra esgrimía que, a causa de ocupar Alvar Núñez el oficio y haber arrendado los diferentes oficios y derechos del almirante, él «non falló quien las quiera arrendar». Debido a ello, le exigía que desistiese de usar el oficio so protestación que fago que el dicho almirante, mi señor, e yo en su nombre, podamos cobrar e cobremos de vos e vuestros bienes mil doblas de oro castellanas —unos 280000 maravedíes de la época ${ }^{34}$ — que en las dichas sus rentas e derechos e guardas e sacas al dicho almirante pertenesçen ${ }^{35}$. Por su parte, Alvar Núñez defendía sus derechos a ejercer su oficio y los tasaba en dos mil doblas de oro de la banda — unos 360000 maravedíes - Sin embargo, fue Rodríguez de la Becerra quien retuvo la lugartenencia, ya que el poder presentado por Alvar Nuñez, solo le daba derecho a llevar la parte del almirante de las tomas e presas que se fasen e toman por la mar y de impedir la saca de pan sin licencia de almirante y del monarca por Jerez y los puertos del litoral gaditano, pero nada decía sobre el ejercicio de la lugartenencia o el juzgado sobre los asuntos marítimos, como sí recogía el nombramiento otorgado al

30 AMJF, AC, 1464, fol. 80v.

31 ADA, 77-53.

32 Según señala, Rafael Sánchez Saus, el almirante también le donó la rica dehesa y torre de Gigonza, en el término municipal de Jerez, Sánchez Saus, Rafael, Linajes medievales de Jerez de la Frontera. Sevilla: Ediciones Guadalquivir, 1996, t. II, p. 41.

33 ADA, 77-55.

34 Ladero Quesada, Miguel Ángel. La Hacienda Real de Castilla (1369-1504). Madrid: Real Academia de la Historia, 2009, p. 767.

35 ADA, 77-53. 
oficial hispalense. Parece que el almirante solo le entregó a su primo Alvar Núñez unas funciones muy concretas en la comarca jerezana, pero en ningún momento la lugartenencia que él se había apropiado a través del poder que presentó en la ciudad ${ }^{36}$.

La situación experimentó un cambio importante a finales de 1465 , cuando fue el propio lugarteniente Juan Sánchez de Bilbao, aunque con el permiso del almirante Fadrique Enríquez, quien separó, esta vez sí, la jurisdicción de Sevilla, el Guadalquivir y los puertos onubenses de la lugartenencia de Jerez e Cadis e villas del Puerto de Santa María e Rota e sus términos e puertos e braços de mar e ríos e esteros. El elegido en el dicho ofiçio de almirantadgo por su lugarteniente fue el vecino jerezano Pedro de Herrera, perteneciente a una de las familias más influyentes en la vida concejili ${ }^{37}$. Se desconoce si existían vínculos personales entre Pedro de Herrera y el lugarteniente hispalense Juan Sánchez que pudiesen justificar su elección. Tampoco aparece mencionado en su documento de nombramiento que se tratase de un arrendamiento — como si ocurría en otras ocasiones-, ni tampoco contamos con datos indirectos que lo confirmen. Entre sus responsabilidades, que tenían fecha de comienzo a 1 de enero de 1466 en adelante en quanto la voluntad del dicho señor almirante y del lugarteniente fuere, se encontraban aver e cobrar todos los derechos e las rentas en el oficio del señor almirante, como la saca de pan y los quintos de las presas, y nombrar oficios de alcaldia e alguasiladgo e escribanias e guardas e otros oficios ${ }^{38}$.

No parece que tuviese una larga vigencia la responsabilidad de Pedro de Herrera. Debió ser relevado en el oficio por Juan Fernández de Melgarejo, que sucedió en la lugartenencia hispalense a Juan Sánchez de Bilbao en 1466. Desconocemos si volvió a ocupar la responsabilidad cuando en el verano de 1468 Juan Sánchez volvió a ejercer el oficio ante el fallecimiento de su predecesor ${ }^{39}$.

En 1471 Pedro de Herrera se presentó ante el concejo jerezano — donde no fue presentado como lugarteniente del almirante-, hablando en voz de Pedro Fernández Marmolejo, y solicitando que se aceptasen los poderes que convertían a este vecino sevillano en lugarteniente del almirante. En el debate concejil, el regidor Gonzalo Pérez de Gallegos, uno de los más veteranos, esgrimió que antes de ser aceptado, se le debía demandar que corrigiese algunas cosas que no devían que venían cometiendo los lugartenientes, como recordaba que ocurrió en 1467, cuando el oficio lo ocupaba Juan Fernández de Marmolejo, padre del referido Pedro Fernández. Entre los diferentes asuntos que le debían ser «apuntados» al nuevo oficial, se encontraban los siguientes ${ }^{40}$ :

1. Que los barqueros jerezanos acusados de sacar pan indebidamente no fuesen juzgados en Sevilla, sino en Jeres ante el juez del almirante.

2. Que los presos por delitos sentenciados por la jurisdicción del dicho almirante sean llevados a la cárcel real de la ciudad y no a otra.

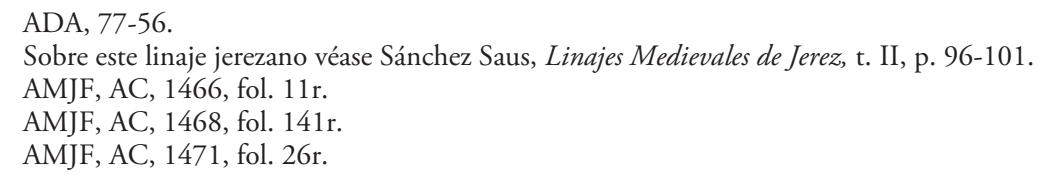


3. Que ningún vecino o morador de Jerez arriende ni tenga el ofçio de lugarteniente salvo el almirante o persona suya o de fuera.

4. Que los derechos del almirantazgo se lleven los mimos que igualmente se llevan y non los impuestos de nuevo.

5. Que los labradores e criadores saquen el tercio de su pan libremente e non le sea enbargado por el dicho almirante pues así le fueron confirmados sus privilegios por Enrique IV.

Pedro de Herrera, en nombre de Pedro Fernández, señalaba que algunos de los temas presentados, como en el caso de los barqueros, el cobro de derechos o la saca del tercio, era la voluntad de los oficiales del almirante respetarlos como siempre se fiso. En el caso de la cárcel, señaló que era costumbre de treinta et quarenta et çinquenta annos de llevar a los reos a una cárcel apartadamente en esta çibdad. En último lugar, en el asunto que más afectaba personalmente a Pedro de Herrera, esgrimía que la elección del lugarteniente syenpre en los tiempos pasados oy dia han ocupado el dicho ofiçio en esta çibdad vecinos della [...] a la libertad del dicho almirante [...] a quien quisiere aver que es persona qual cumple $e^{41}$. Es probable que Pedro de Herrera se mantuviese algunos años como lugarteniente de Jerez, al menos hasta 1478, cuando la lugartenencia de todo el reino paso a manos de Ruy González de Portillo ${ }^{42}$, aunque la pérdida de actas capitulares en esta ciudad para la década de 1470 no permite arrojar más luz sobre el asunto.

En el año 1480 sabemos que el propio almirante nombró a Gómez de Herrera, hijo del regidor sevillano Diego López de Herrera, como lugarteniente de Jerez y del Obispado de Cádiz, y así fue confirmado y recibido por el concejo el 2 de junio (Tabla 2). La duración contenida en su carta de nombramiento se extendía durante cuatro años a partir del 1 de junio de $1480^{43}$. Por motivos que desconocemos, probablemente la epidemia de peste que asoló la comarca en el verano de $1480^{44}$, Gómez de Herrera no ejerció su oficio, ya que lo cedió inmediatamente a Juan de Arauz, jurado de Sevilla y receptor de la lugartenencia sevillana. Este a su vez lo cedió al trapero jerezano Rodrigo de Molina. La fiebre inquisitorial que comenzó en el reino explican que tanto Molina como Arauz abandonasen las ciudades y sus oficios y el almirante se viese obligado a nombrar el 31 de julio de 1481 a su criado Francisco de Soria para que se encargase de la gestión del almirantazgo de todo el reino de Sevilla ${ }^{45}$. Este último apenas estuvo unas semanas en el cargo, ya que el almirante arrendó el oficio de nuevo al mercader vallisoletano Ruy González de Portillo, que se mantuvo al frente del oficio hasta 1489, cuando fue susti-

41 AMJF, AC, 1471, fol. 26v.

42 Navarro Sainz, José María, El concejo de Sevilla en el reinado de Isabel I (1474-1504). Sevilla: tesis inédita, 2004, p. 760. Enlace: http://hdl.handle.net/11441/15219 [Consultada 9-03-2020].

43 AMJF, AC, 1480, fols. 13v-16v.

44 Gil Fernández, Juan, Los conversos y la Inquisición sevillana: El distrito y sus hombres. Sevilla: Universidad de Sevilla, 2003, p. 217.

45 Documento inserto en Fernández de Navarrete, Martín, Colleción de los viajes y descubrimientos que hicieron por mar los españoles desde fines del siglo XV. Madrid: Imprenta Real, 1825, t. I, p. 424. 
tuido por su hijo Nicolás Portillo ${ }^{46}$. Fue precisamente este último quien se encargó de la lugartenencia de Jerez durante la década de 1480 — la de Sevilla fue delegada en Jorge de Tordesillas_ ${ }^{47}$. Entre 1489 y 1491 Nicolás de Portillo relevó a su padre en Sevilla, ocupando la lugartenencia jerezana por nombramiento suyo, al menos en 1491, Juan Rodríguez de Salazar. Tanto este como su sucesor, el jerezano Sancho de Toledo - que ocupó el oficio en 1492 por nombramiento del lugarteniente de Sevilla y criado del almirante Francisco de Soria-, fueron muy criticados por el concejo y vecinos de Jerez por los abusos que cometían: el primero por gravar indebidamente la exportación de vinos; el segundo por apresar indiscriminadamente a los vecinos ${ }^{48}$.

En 1498 otro criado del almirante, el vallisoletano Pedro Niño, sustituyó a Soria al frente de la lugartenencia del reino de Sevilla. Parece que ya había ocupado algunos meses la lugartenencia de Jerez, donde pudo haber entrado en contacto con el jerezano Luis Ortiz de Gatica, quien ocupará el oficio delegado al sur del Guadalquivir durante veinte años. Este último, personaje sobre el que más datos se han conservado, pertenecía a uno de los linajes caballerescos de segunda fila de la ciudad ${ }^{49}$, aquellos que no gozaban de una posición destacada en la institución concejil ${ }^{50}$. Ello no le impidió ascender rápidamente, como ahora veremos, gracias a la privanza del almirante.

Con toda probabilidad, la relación entre Luis Ortiz y el almirante Fadrique Enriquez, que se extendió como mínimo desde 1498 hasta la muerte de primero en 1522 —el segundo falleció en 1538 - y se dilató con su primogénito Juan Ortiz, se encuentre en la intermediación del mencionado Pero Nińo. Ya en 1498, Ortiz de Gatica aparece como su representante en Jerez. Ese año defendía en nombre del lugarteniente Niño los derechos del almirantazgo en un largo pleito que duró más de una década entre el almirante y el jerezano Pedro de Estopiñán — conquistador de Melilla y criado del duque de Medina Sidonia - sobre los derechos de una cabalgada ${ }^{51}$. Al ańo siguiente, Luis Ortiz, ya ocupaba oficialmente la lugartenencia de Jerez, mientras que la de Sevilla siguió en manos de Pero Nińo hasta $1508^{52}$.

46 Nicolás, mercader como su padre, era mayordomo del concejo de Valladolid cuando fue nombrado lugarteniente de Jerez en 1482, AMJF, AC, 1483, fol. 9r. Cuando en 1491 abandonó Andalucía, volvió a ejercer su antiguo oficio, hasta que lo cedió a su pariente Rodrigo de Portillo en 1494, AGS, RGS, 1494, leg. 2, fol. 23.

\footnotetext{
47 AMJF, AC, 1483, fol. 9r.

48 AMJF, AC, 1491, fol. 203r y 1492, fol. 45r.

49 Sánchez Saus, Linajes medievales de Jerez, t. I, pp. 92-93.

50 Ruiz Pilares, La sociedad política, pp. 147-150.

51 Aznar Vallejo, "Las rentas del almirantazgo", p. 143.

52 Calderón Ortega, El Almirantazgo, p. 213
} 
LORENZO LAGE ESTRUGO Y ENRIQUE JOSÉ RUIZ PILARES

LA ADMINISTRACIÓN DEL ALMIRANTAZGO EN CASTILLA A FINALES DE LA EDAD MEDIA: LOS LUGARTENIENTES DE SEVILLA Y JEREZ DE LA FRONTERA

Tabla 2. Lugartenientes de Sevilla y Jerez $(1480-1522)^{53}$

\begin{tabular}{|c|c|c|c|c|c|}
\hline \multicolumn{3}{|c|}{ Lugartenientes en Sevilla } & \multicolumn{3}{|c|}{$\begin{array}{c}\text { Lugartenientes en Jerez y el Obispado de } \\
\text { Cádiz }\end{array}$} \\
\hline Nombre & Años & Otros & Nombre & Años & Otros \\
\hline Juan de Arauz & 1480 & $\begin{array}{l}\text { jurado de Sevilla; } \\
\text { arrendador }\end{array}$ & \begin{tabular}{|l|} 
Gómez de \\
Herrera \\
\end{tabular} & 1480 & \begin{tabular}{|l|}
$\begin{array}{l}\text { hijo de regidor } \\
\text { sevillano }\end{array}$ \\
\end{tabular} \\
\hline Francisco de Soria & 1481 & criado del almirante & \begin{tabular}{|l|} 
Francisco de \\
Soria
\end{tabular} & 1481 & criado del almirante \\
\hline $\begin{array}{l}\text { Ruy González de } \\
\text { Portillo }\end{array}$ & $\begin{array}{c}1482- \\
1488\end{array}$ & $\begin{array}{l}\text { arrendador; vecino de } \\
\text { Valladolid }\end{array}$ & \begin{tabular}{|l} 
Nicolás de \\
Portillo (hijo de \\
Ruy González)
\end{tabular} & $\begin{array}{c}1482- \\
1488\end{array}$ & $\begin{array}{l}\text { arrendador; vecino } \\
\text { de Sevilla }\end{array}$ \\
\hline \multirow{2}{*}{ Nicolás Portillo } & \multirow{2}{*}{$\begin{array}{l}1489- \\
1491-\end{array}$} & \multirow{2}{*}{$\begin{array}{l}\text { arrendador; vecino de } \\
\text { Valladolid }\end{array}$} & Sancho de Jofre & $\begin{array}{c}1489- \\
1491\end{array}$ & \begin{tabular}{|l|} 
escudero del \\
almirante
\end{tabular} \\
\hline & & & \begin{tabular}{|l|} 
Juan Rodríguez \\
de Salazar
\end{tabular} & 1491 & --- \\
\hline \multirow{2}{*}{$\begin{array}{l}\text { Francisco de } \\
\text { Soria }\end{array}$} & \multirow{2}{*}{$\begin{array}{c}1491- \\
1498\end{array}$} & \multirow{2}{*}{ criado del almirante } & Sancho de Toledo & \begin{tabular}{|c|}
$1491-$ \\
1492 \\
\end{tabular} & vecino de Jerez \\
\hline & & & Pedro Niño & 1497 & criado del almirante \\
\hline Pedro Niño & $\begin{array}{l}1498- \\
1508\end{array}$ & criado del Almirante & \multirow{5}{*}{$\begin{array}{l}\text { Luis Ortiz de } \\
\text { Gatica }\end{array}$} & \multirow{5}{*}{$\begin{array}{l}1499- \\
1522\end{array}$} & \multirow{5}{*}{$\begin{array}{l}\text { criado del almirante; } \\
\text { vecino de Jerez }\end{array}$} \\
\hline Pedro de Acuña & 1508 & vecino de Sevilla & & & \\
\hline $\begin{array}{l}\text { Alfonso Jofre } \\
\text { Tenorio }\end{array}$ & 1512 & vecino de Sevilla & & & \\
\hline $\begin{array}{l}\text { Francisco de } \\
\text { Mendoza }\end{array}$ & 1516 & vecino de Sevilla & & & \\
\hline Juan de Almansa & $\begin{array}{c}1518- \\
1522\end{array}$ & $\begin{array}{l}\text { jurado de Sevilla; } \\
\text { arrendador }\end{array}$ & & & \\
\hline
\end{tabular}

Durante los más de veinte años que Luis Ortiz estuvo al frente de la lugartenencia — coincidiendo con el fortalecimiento del oficio por parte de su señor Fadrique — su influencia en la comarca debió ser muy importante: en más de una ocasión en la documentación de la época se le denomina como almirante de Jerez. Durante esos años consiguió defender los derechos de la institución, no sin problemas y largos litigios — como el ya mencionado contra Estopińán con resultado exitoso ${ }^{54}$ - , frente a los grandes señores y concejos de la zona. Entre ellos debemos destacar los numerosos conflictos entablados con el duque de Medina Sidonia, el principal señor del litoral atlántico andaluz. A modo

53 Calderón Ortega, El Almirantazgo, p. 213 y 377; Navarro Sainz, José María. El concejo de Sevilla, pp. 174-175; Romeu de Armas, Antonio. Nueva luz sobre las Capitulaciones de Santa Fe de 1492 concertadas entre los Reyes Católicos y Cristóbal Colón. Madrid: Consejo Superior de Investigaciones Científicas, 1985, p. 202; AMJF, AC, 1480, fol. 4r; 1482, fol. 9r; 1489, fol. 166r; 1491, fol. 92r; 1492, fol. 92r; AGS, RGS, 1491-04, fol. 164.

54 AMJF, AHPNJF, 1522, Luis de Llanos, fol. 1039v. 
de ejemplo, en 1501 consiguió el compromiso de los representantes del rey de Portugal en la Bahía de Cádiz, de que los derechos sobre el pan exportado desde los puertos señoriales de los Medina Sidonia se pagasen al señor almirante e a él en su nombre [...] aqui en Jerez, y no al duque ${ }^{55}$. Otro conflicto destacado tuvo lugar en 1505 contra el duque de Medinaceli y su concejo de El Puerto de Santa María a cuenta de un centenar de espadas exportadas al Norte de África sin licencia y sin pagar los derechos pertenecientes al almirante ${ }^{56}$. Como último ejemplo, en su último año de vida -1522-, se vio sumido en un conflicto contra los recaudadores del almojarifazgo de Jerez, quiénes, según Ortíz de Gatica, descontentos que yo sea juez [en nombre del almirante] han enviado otros [...] a traer vara [de la justicia] y hará otras estorsiones a propósito de los dichos amojarifes y en perjuisio desta çibdad, $\$^{57}$.

Tras años de servicios al almirante, en 1522 tuvo lugar un acontecimiento que dio el espaldarazo definitivo en su carrera política: el acceso el regimiento de la ciudad de Jerez. Ello no puede entenderse sin la Guerra de las Comunidades, donde participó a las órdenes de su superior. Fadrique Enríquez, uno de los gobernadores del reino, lideró la victoria contra los rebeldes en la batalla de Villalar el 23 de abril de $1521^{58}$. En la financiación y apoyo militar de este conflicto participó activamente Luis Ortiz, quien se encargó de conseguir el préstamo de 1570775 maravedíes de una serie de mercaderes locales para la gente de Jerez que él llevo en servicio de los monarcas ${ }^{59}$. En recompensa, el monarca le concedió - entre otras mercedes - un oficio de regidor en Jerez a Fadrique, el cual cedió inmediatamente a su criado y lugarteniente -8 de diciembre de $1521-$. En la carta de cesión, el almirante lo denomina mi primo Luis Ortiz, siendo aceptado por el concejo jerezano el 13 de enero de $1522^{60}$.

La muerte le sobrevino a causa de la peste pocos meses después —-mayo de 1522—, aunque la posición sociopolítica y económica que había alcanzado fue mantenida y consolidada por sus hijos. Su primogénito, Juan Ortiz de Gatica, ocupó la veinticuatría paterna y mantuvo la estrecha relación con el almirante de Castilla, sucediéndolo como lugarteniente ${ }^{61}$. Además, invirtió la fortuna obtenida al servicio de su señor en la adquisición de numerosas tierras e inmuebles urbanos, entre los que destacan más de 100 aranzadas de olivar, que lo convirtieron en un importante terrateniente de la ciudad ${ }^{62}$.

55 AMJF, AHPNJF, 1501, Juan de Román, fol. 451r.

56 Lage Estrugo, «El Almirantazgo y la Bahía de Cádiz», pp. 161-162.

57 AMJF, AC, 1522, fol. 766r.

58 Sobre el desarrollo de este conocido episodio de la historia política castellana véase Martínez Gil, Fernando (coord.), Entorno a las comunidades de Castilla. Actas del congreso internacional «Poder, conflicto y revuelta en la España de Carlos I", Cuenca: Universidad de Castilla-La Mancha, 2002 o el ya clásico trabajo de José Antonio Maravall, Las Comunidades de Castilla: una primera revolución moderna, Madrid: Alianza Universal, 1981 (1970).

59 Él se encargó también de su posterior recaudación a costa de recaudar de las rentas reales de la ciudad, tanto de las alcabalas como del almojarifazgo, AMJF, AHPNJF, 1521, Luis de Llanos, 596r.

60 AMJF, AC, 1522, fol. 588r.

${ }_{61}$ Mingorance Ruiz, José Antonio. Los extranjeros en Jerez de la Frontera a fines de la Edad Media. Universidad Pablo de Olavida (Sevilla): tesis inédita, 2013, p. 758.

62 Algunas notas sobre el patrimonio de este personaje en Martín Gutiérrez, Emilio. «Poder, paisaje, estructura de la propiedad y sistemas de explotación: las tierras del olivar en Jerez de la Frontera durante el 
Analizada la figura del lugarteniente del litoral gaditano en el tránsito de los siglos XV y XVI, creemos oportuno reflexionar sobre uno de los aspectos a los que menos atención ha prestado la historiografía sobre este oficio castellano: el ámbito «real» de ejercicio de la jurisdicción del almirantazgo, y en el caso que ataña a este apartado, del territorio al sur del Guadalquivir. En 1465, Pedro de Herrera se hizo cargo del ejercicio de su lugartenencia sobre Jerez e Cadis e villas del Puerto de Santa María e Rota e sus términos e puertos e braços de mar e ríos e esteros. Similar jurisdicción se explicita en el nombramiento de Gómez de Herrera en 1481: el Puerto de Santa María, Sanlúcar, Jerez y Cádiziz. En este segundo caso, al incluir Sanlúcar, se mencionaban las localidades más importantes del litoral que abarcaba desde la desembocadura del Guadalquivir a la Bahía de Cádiz ${ }^{64}$.

A comienzos del siglo XVI, cuando se hizo con el control del oficio Luis Ortiz de Gatica, la documentación jerezana aporta datos mucho más precisos. En un poder notarial de 1516 se le menciona a Luis Ortiz como lugarteniente en Jerez e los puertos de su comarca ${ }^{65}$. Esa comarca sabemos que abarca como mínimo el litoral desde Sanlúcar, en la desembocadura del río Guadalquivir, hasta el río Barbate en Vejer (Mapa 1), como puede intuirse de diferentes actuaciones que tuvo que llevar a cabo Luis Ortiz contra el duque de Medina Sidonia a comienzos del siglo xvi. No obstante, sería lógico pensar que su jurisdicción abarcase hasta el estrecho y ciudad de Gibraltar, ya que a partir de esta localidad hacia el interior del Mediterráneo la jurisdicción pertenecía al lugarteniente del almirante en el reino de Granada ${ }^{66}$. La ausencia de referencias parece indicar que la capacidad real del lugarteniente jerezano se concentraba en ámbito formado por el triángulo, Jerez-Cádiz-Sanlúcar. Nada extraño, si tenemos en cuenta que era el epicentro de la actividad comercial internacional — junto a Sevilla— del litoral atlántico andaluz en el tránsito de la Edad Media a los tiempos modernos ${ }^{67}$.

siglo xv y el primer cuarto del xvI». En I Congreso de la Cultura del Olivo. Jaén: Instituto de Estudios Giennenses, 2007, pp. 185-186.

63 ADA, c. 77-91.

64 Una interesante descripción de este espacio litoral en Muńoz Gómez, Víctor. «Puertos, abras, cabos e islas: la topografía medieval de la costa atlántica de Andalucía a través de las cartas portulanas (ss. XV-XVI)». En Aznar Vallejo, Eduardo y González Zalacaín (coords.), De mar a mar: los puertos castellanos en la Baja Edad Media. La Laguna: Universidad de la Laguna, 2015, pp. 147-178.

65 AMJF, AHPNJF, 1516, Luis de Llanos, fol. 766v.

${ }_{66}$ Sobre el particular véanse los trabajos recogidos en la monografía Cruces Blanco, López de Coca Castañer y Ruiz Povedano (coords.), Málaga y el almirantazgo mayor del reino de Granada.

${ }_{67}$ Aznar Vallejo, Eduardo. «Andalucía y el Atlántico Norte a fines de la Edad Media». Historia. Instituciones. Documentos, 2003, vol. 30, pp. 103-120; Bello León, Juan Manuel. «El Reino de Sevilla en el comercio exterior castellano (siglos xIv y xv)». En Casado Alonso, Hilario (ed.). Castilla y Europa. Comercio y Mercaderes en los siglos XIV, XV y XVI. Burgos: Diputación provincial de Burgos, 1995, pp. 57-80; Otte Sander, Enrique. Sevilla y sus mercaderes a fines de la Edad Media. Sevilla: Fundación El Monte, 1996; González Arévalo, Raúl. «Integración y movilidad social de las naciones italianas en la Corona de Castilla: genoveses, florentinos y venecianos en la Andalucía bajomedieval». En Tanzini, Lorenzo y Tognetti, Sergio (coords.). La mobilità sociale nel Medioevo italiano. Competenze, conoscense e saperi tra professioni e ruoli social (secc. XII-XV). Roma: Viella, 2016, pp. 375-401. 


\section{Conclusiones}

Como puede observarse, el oficio de lugarteniente había evolucionado a lo largo de los años finales del siglo xv, enfocado plenamente a la percepción de rentas, frecuentemente arrendado por individuos de extracción media dentro de las ciudades andaluzas de la época. Personajes, los lugartenientes, que buscaban en el arrendamiento de tal responsabilidad una oportunidad de incrementar su patrimonio mediante la influencia económica y social proporcionada por este oficio; que era, realmente, representación física de los intereses del almirantazgo en un territorio concreto.

Ello es una muestra de la naturaleza del almirantazgo en tiempos de Fadrique Enríquez de Cabrera: prácticamente un honor patrimonial de los Enríquez y una fuente de rentas asociadas, desligado de su función como cargo militar con responsabilidades navales. El rol de don Fadrique como almirante sólo sería ejercido en dos ocasiones puntuales, una durante el asedio de Málaga y la segunda durante la llamada Armada de Flandes ${ }^{68}$. Las pretensiones del sobredicho noble castellano para la institución pasaban por una confirmación de los privilegios de los cuales habían disfrutado su padre, abuelo y bisabuelo, así como una expansión de sus derechos a nuevas áreas territoriales: el almirantazgo de Granada, que sometía a su jurisdicción puertos tan prósperos como Málaga o Almería. Sin embargo, los tradicionales roles de gestión de las flotas reales y recursos asociados se hallaban totalmente ausentes o en franca y total decadencia, en manos de agentes de la corona durante el reinado de los Reyes Católicos.

Sin embargo, no debe obviarse la influencia de la institución bajo Fadrique Enríquez de Cabrera, en buena medida se debe al señalado status de dicho noble en la corte real, teniendo una incidencia destacable durante el reinado de los Reyes Católicos, como miembro del consejo y la casa regias. Ello evitó la definitiva decadencia de los derechos y privilegios del almirantazgo — en el terreno arancelario y rentista—, que se preservaron mientras vivió el noble castellano, hasta su fallecimiento en 1538, bien entrado el reinado de Carlos I; del que fue co-gobernador — junto con Adriano de Utrecht— del reino en la década de 1520, durante las Comunidades.

La continuidad de la figura del lugarteniente es una muestra de la resiliencia de la institución, su versatilidad y su durabilidad. Realmente no eran sino una manifestación física de la capacidad del almirantazgo para aplicar su jurisdicción en el complejo «mosaico» de la Bahía de Cádiz. Así como, su propia evolución en el tiempo es un testimonio de los cambios socio-económicos y políticos del reino de Sevilla a lo largo del siglo xv. Un oficio sevillano, arrendado, se tornó en una figura institucional polifacética, en el verdadero representante del gran oficio castellano-leonés en la región donde había tenido su desarrollo y expansión. Asimismo, el desdoblamiento de la lugartenencia ejemplifica

68 El almirante estuvo muy presente en la organización de la flota, intercambiando memoriales con los Reyes Católicos y teniendo influencia en su logística. La mayor parte del trabajo, sin embargo, acabó recayendo en individuos como el armador bilbaíno Juan de Arbolancha, el obispo Juan Rodríguez de Fonseca o incluso el almirante de la mar Océana, Cristóbal Colón, al cual se consultó sobre la ruta a seguir. León Guerrero, María Montserrat. «La armada de Flandes y el viaje de la princesa Juana». Revista de Estudios Colombinos, 2009, vol. 5, pp. 53-62; Ladero Quesada, Miguel Ángel. La armada de Flandes: un episodio en la politica naval de los Reyes Católicos (1496-1497). Madrid: Real Academia de la Historia, 2003, pp. 75-84. 
los cambios y transformaciones en las estructuras regionales, con el surgimiento de un litoral andaluz cada vez más rico y potente, con una mayor pujanza económica dentro del conjunto del reino, lo cual hizo necesaria la presencia de oficiales específicos en los ascendentes puertos gaditanos. El oficio, por tanto, es un reflejo del propio contexto, desde su surgimiento como un arrendamiento parcial de rentas en los años finales del siglo XIV a los lugartenientes de inicios del XVI. Individuos de confianza, pertenecientes a círculos con fuertes intereses mercantiles, de orígenes urbanos y dignidad caballeresca, que gestionaban un enorme número de derechos jurisdiccionales y que realmente eran el almirantazgo, su cara visible, para todos aquellos cuyo día a día estaba ocupado por los asuntos y negocio de la mar.

La supervivencia hasta nuestros días de numerosos testimonios de la actividad de lugartenientes del almirantazgo en la Bahía de Cádiz en dichos años es, por tanto, un ejemplo paradigmático de la actividad continuada de la institución en la región, así como de la progresiva importancia de la zona en la vida económica del reino de Castilla en su conjunto. Sin embargo, el surgimiento de nuevas instituciones dedicadas a la explotación de los nuevos territorios conquistados en América y el asentamiento de un sólido autoritarismo regio acabarían por finiquitar el almirantazgo, cuya influencia teórica se disipa totalmente a mediados del siglo XVI, pasando a ser tan virtualmente irrelevante como el oficio de condestable de Castilla, su homólogo más próximo. Únicamente un honor pasado de padres a hijos dentro de un linaje, sin mayor relevancia práctica.

\section{REFERENCIAS BIBLIOGRÁFICAS}

Aznar Vallejo, Eduardo. «Andalucía y el Atlántico Norte a fines de la Edad Media». Historia. Instituciones. Documentos, 2003, vol. 30, pp. 103-120.

Aznar Vallejo, Eduardo. «Las rentas del Almirantazgo castellano. Entre la ley y la costumbre». En la España Medieval, 2014-2015, vol. 37, pp. 131-163.

Bello León, Juan Manuel. «El Reino de Sevilla en el comercio exterior castellano (siglos XIV y Xv)». En Casado Alonso, Hilario (ed.). Castilla y Europa. Comercio y Mercaderes en los siglos XIV, XV $y$ XVI. Burgos: Diputación provincial de Burgos, 1995, pp. 57-80.

Bello León, Juan Manuel. «Mercaderes del siglo xv en Jerez de la Frontera». Historia. Instituciones. Documentos, 2014, vol. 41, pp. 11-44.

Calderón Ortega, José Manuel. El almirantazgo de Castilla: historia de una institución conflictiva. Alcalá de Henares: Universidad de Alcalá de Henares y Fundación duque de Alba, 2003.

Calderón Ortega, José Manuel y Díaz González, Francisco Javier. «Los almirantes y la política naval de los reyes de Castilla en el siglo xiII». Anuario de la Facultad de Derecho, 1988-1989, vol. 8, pp. 103-126.

Casado Alonso, Hilario. "Comprar y vender en las ferias de Castilla durante los siglos XV y XVI». En Faire son marché au Moyen Âge: Mediterranée occidentale, XIIT-XVI siècle. Madrid: Casa de Velázquez, 2018, pp. 111-131.

Collantes de Terán Sánchez, Antonio. «Los señoríos andaluces. Análisis de su evolución territorial en la Edad Media». Historia. Instituciones. Documentos, 1979, vol. 6, pp. 89-112.

Cruces Blanco, Esther, López de Coca Castañer, José Enrique y Ruiz Povedano, José María (coords.). Málaga y el almirantazgo mayor del reino de Granada (1510-1538). Revolución y poder. Malaga: Fundación Unicaja, 2017. 
Fernández Conti, Santiago. "Carlos V y la alta nobleza castellana: el almirante don Fadrique Enríquez». En Martínez Millán, José, Rivero Rodríguez, Manuel y Álvarez-Ossorio Alvariño, Antonio (coords.). Carlos Vy la quiebra del humanismo político en Europa (1530-1558), Madrid: Sociedad Estatal para la Conmemoración de los centenarios de Carlos V y Felipe II, 2001, pp. 29-51.

Fernández de Oviedo, Gonzalo [1548], edición de Fabregat Barrios, Santiago. Libro de la Cámara Real del Principe Don Juan, oficios de su casa y servicio ordinario. Valencia: Universidad de Valencia, 2006.

Franco Silva, Alfonso. Estudios sobre la nobleza y el régimen señorial en Andalucía, siglos XIV-mediados del XVI. Granada: Editorial Universidad de Granada, 2006, pp. 226-238.

Franco Silva, Alfonso, Cruz Mariño, Rafael. «Juan Pacheco, privado de Enrique IV, y el oficio de corregidor de Jerez de la Frontera». En la España Medieval, 2012, vol. 35, pp. 285-316.

García de Castro, Francisco Javier, La marina de guerra de la corona de Castilla en la Baja Edad Media. Desde sus orígenes hasta el reinado de Enrique IV. Universidad de Valladolid (Valladolid): tesis inédita, 2011. Enlace: http://uvadoc.uva.es/handle/10324/889 [Consultada el 19 del 11 de 2020].

Gil Fernández, Juan, Los conversos y la Inquisición sevillana: El distrito y sus hombres. Sevilla: Universidad de Sevilla, 2003.

González Arévalo, Raúl. «Integración y movilidad social de las naciones italianas en la Corona de Castilla: genoveses, florentinos y venecianos en la Andalucía bajomedieval». En Tanzini, Lorenzo y Tognetti, Sergio (coords.). La mobilità sociale nel Medioevo italiano. Competenze, conoscense e saperi tra professioni e ruoli social (secc. XII-XV). Roma: Viella, 2016, pp. 375-401.

González Arce, José Damián. «Trabajar para el príncipe. Los salarios de los servidores en la casa del príncipe de Asturias y Gerona (Juan de Aragón y Castilla, 1478-1497)». Anuario de Estudios Medievales, vol. 39, n. ${ }^{\circ}$ 2, 2009, pp. 777-842.

González Arce, José Damián. «Pugnas entre monarquía y aristocracia por el control de los almojarifazgos costeros y otros derechos aduaneros de la Andalucía atlántica en el reinado de los Reyes Católicos». Anuario de Estudios Medievales, 2017, vol. 47, n. ${ }^{\circ}$ 1, pp. 73-106.

González Zalacaín, Roberto. «De puerto a puerto: las relaciones entre los puertos de la Bahía de Cádiz (siglos XV-Xvi)». En Aznar Vallejo, Eduardo y González Zalacaín (coords.). De mar a mar: los puertos castellanos en la Baja Edad Media. La Laguna: Universidad de la Laguna, 2015, pp. 147-178.

Houben, Hubert. Roger II of Siciliy: a ruler between East and West. Cambridge: Cambridge University Press, 2002.

Ladero Quesada, Miguel Ángel. «Los señoríos medievales en el ámbito de Cádiz y Jerez de la Frontera». En la España Medieval, 1982, vol. 2, pp. 543-572.

Ladero Quesada, Miguel Ángel. Andalucía a fines de la Edad Media: estructuras, valores, sucesos. Cádiz: Universidad de Cádiz, 1999.

Ladero Quesada, Miguel Ángel. La armada de Flandes: un episodio en la política naval de los Reyes Católicos (1496-1497). Madrid: Real Academia de la Historia, 2003.

Ladero Quesada, Miguel Ángel. La Hacienda Real de Castilla (1369-1504). Madrid: Real Academia de la Historia, 2009.

Lage Estrugo, Lorenzo. «El Almirantazgo y la Bahía de Cádiz en la Baja Edad Media: Competitividad señorial, rentas alienadas y proyectos frustrados». Riparia, 2019, Suplemento 2, pp. 143-172.

Lage Estrugo, Lorenzo. «El almirantazgo de la mar océana de Cristóbal Colón y el almirantazgo castellano medieval». En Barrientos Márquez, María del Mar y Gullón Abao, Alberto (coords.). América y el Mar. Cádiz: Universidad de Cádiz, 2019, pp. 25-40. 
León Guerrero, María Montserrat. «La armada de Flandes y el viaje de la princesa Juana». Revista de Estudios Colombinos, 2009, vol. 5, pp. 53-62.

Martín Gutiérrez, Emilio. «Poder, paisaje, estructura de la propiedad y sistemas de explotación: las tierras del olivar en Jerez de la Frontera durante el siglo xv y el primer cuarto del xvI». En $I$ Congreso de la Cultura del Olivo. Jaén: Instituto de Estudios Giennenses, 2007, pp. 177-198.

Martín Gutiérrez, Emilio y Ruiz Pilares, Enrique José. El viñedo en Jerez de la Frontera durante el siglo XV. Un mercado de trabajo en torno al vino. Jerez de la Frontera: Peripecias Libros, 2019.

Martínez Sopena, Pascual. El estado señorial de Medina de Rioseco bajo el almirante Alfonso Enríquez (1389-1430). Valladolid: Universidad de Valladolid, 1977.

Mingorance Ruiz, José Antonio. Los extranjeros en Jerez de la Frontera a fines de la Edad Media. Universidad Pablo de Olavide (Sevilla): tesis inédita, 2013. Enlace: http://hdl.handle. net/10433/755 [Consultada el 11-02-2020].

Mitre Fernández, Emilio y González Crespo, Esther. «El Maestre don Fadrique y su descendencia en la formación de la nobleza trastamarista». Hidalguía: la revista de genealogía, nobleza y armas, 2016, vol. 373, pp. 779-808.

Muñoz Gómez, Víctor. «Puertos, abras, cabos e islas: la topografía medieval de la costa atlántica de Andalucía a través de las cartas portulanas (ss. XV-XVI)». En Aznar Vallejo, Eduardo y González Zalacaín (coords.), De mar a mar: los puertos castellanos en la Baja Edad Media. La Laguna: Universidad de la Laguna, 2015, pp. 147-178.

Muñoz Gómez, Victor. "Compañeros de armas: ejemplos de sociabilidad en las fronteras marítimas ibéricas durante el reinado de Fernando I de Aragón». Vegueta, 2018, vol. 18, pp. 133-166.

Navarro Sainz, José María, El concejo de Sevilla en el reinado de Isabel I (1474-1504). Universidad de Sevilla: tesis inédita, 2004. Enlace: http://hdl.handle.net/11441/15219 [Consultada el 9-03-2020].

Ortega Gato, Esteban. «Los Enríquez, almirantes de Castilla». En Publicaciones de la Institución Tello Téllez de Meneses, 1999, vol. 70, pp. 23-65.

Otte Sander, Enrique. Sevilla y sus mercaderes a fines de la Edad Media. Sevilla: Fundación El Monte, 1996.

Ruiz Pilares, Enrique José. La sociedad política de Jerez de la Frontera a finales de la Edad Media, Cádiz: Universidad de Cádiz, 2020.

Ruiz Pilares, Enrique José. «Jerez de la Frontera: el gran centro productor del complejo portuario de la Bahía de Cádiz a finales de la Edad Media». Estudios sobre Patrimonio, Cultura y Ciencias Medievales, 2018, vol. 20, pp. 355-386.

Romeu de Armas, Antonio. Nueva luz sobre las Capitulaciones de Santa Fe de 1492 concertadas entre los Reyes Católicos y Cristóbal Colón. Madrid: Consejo Superior de Investigaciones Científicas, 1985.

Sánchez Saus, Rafael, Linajes sevillanos medievales. Sevilla: Ediciones Guadalquivir, 1991.

Sánchez Saus, Rafael, Linajes medievales de Jerez de la Frontera. Sevilla: Ediciones Guadalquivir, 1996.

Soria Mesa, Enrique. La nobleza en la España moderna: cambio y continuidad. Madrid: Marcial Pons, 2007.

Unger, Richard W. «Admiralties and Warships of Europe and the Mediterranean». En Unger, Richard W. Ships and Shipping in the North Sea and Atlantic, 1400-1800. Oxford: Routledge, 2018, pp. 34-42. 